Short Note

\title{
When we put spatial causalities first in production of scientific knowledge: notes on the geography of science
}

\author{
Mahmood Shoorcheh ${ }^{*}$
}

How to cite this paper :

Shoorcheh, M. (2021). When we put spatial causalities first in production of scientific knowledge: notes on the geography of science. Universal Journal of Social Sciences and Humanities, 1(1). DOI:

https://doi.org/ujssh.2021.010103. Retrieved from http://www.scipublications.com/journal/in-

dex.php/ujssh/article/view/28
Received: May 3, 2021

Accepted: June 12, 2021

Published: June 13, 2021

Copyright: (c) 2021 by the authors. Submitted for possible open access publication under the terms and conditions of the Creative Commons Attribution (CC BY) license (http://creativecommons.org/licenses /by/4.0/).
${ }^{1}$ Faculty of Geographical Sciences and Planning, University of Isfahan: Isfahan, Iran

*Correspondence: Mahmood.Shoorcheh@gmail.com

\begin{abstract}
Any history of science has its own geography as well. Geographers of science have tried to put science in its place. They study the socio-spatial settings in which scientific knowledge was generated, displayed and legitimated. For them, science is socially constructed in spatialities and temporalities. The main question should to be "how" spatialities are constructing scientific knowledge via its "causalities". Geography of science is not just about special places, locations, and regions in which scientific knowledge is unequally produced/consumed and circulated or how the use of scientific knowledge can lead to the production and reproduction of unique places and spaces. Geography of science is also about a variety set of spatial causalities through which scientific knowledge can be formed and transformed. This also means that the innovative knowledge or ideas development takes place not only in the spatial contexts but because of the spatial causalities which rise from the myriad interlinkages and interdependencies among places. These imperatives of spatial significance operate across many spatial scales from the body to the global. Hence, in our increasingly glocalized world, we must seek knowledge in spatial encounters and betweenness of places, not merely within spaces and places.
\end{abstract}

Keywords: Spatial Causalities, Geographies of Science, Geographical Turn.

\section{Introduction}

When I first encounter this brilliant idea from historical geographer Charles Withers that, "if we can have a history of science, a philosophy of science and a sociology of science, why not a geography and, even, a historical geography of science?" [1] (p. 9) it seems to me really like an undiscovered continent. The first lesson I learned through this journey was that historians of geography have failed to attend to the spatial components of their tradition's history in one sense; that is the history of geography has frequently been written with little reference to the placing of geographical knowledge in its various spatialities or putting science in its place; Because we always act on this widespread assumption that securing credibility and achieving objectivity required "placelessness" [2-4]. On the other hand, to be modern is to be beyond geography, but to paraphrase historian of science Bruno Latour, if aspatiality is modernity, we are not and have never been modern [2].

My reason for leaving this short note is that scientific knowledge has a spatial nature; I strongly believe that scientific knowledge shapes and is shaped by the spatiality; scientific knowledge generates and is generated by spatial encounters in terms of relational spatialities networks in a world of contingency and constant becoming. Therefore, this note tried to show very briefly that the geographies of science are not simply about spatial disparities of knowledge but also about the role that "spatial causalities" can play in the generation of scientific knowledge.

\section{Spatialising historicality and sociality}


Interest in the geography of scientific knowledge has been of the significant domain in the past 20 years. But no serious attention has ever been taken to geographicalism of scientific knowledge prior to the "spatial turn" in philosophy, literature, and humanities/social sciences with the advent of some of the 1960s Parisians, including Foucault, Deleuze, and Lefebvre, and the revival and expansion of their thought after the 1980s. In the late 1980s, as cultural and social studies experienced a spatial turn, geographers began experiencing a concomitant "cultural turn". The growing currency of geographicalism after the spatial turn is closely linked to the recognition of the key role of spatialities in the processes by which people (re)construct their understandings of the world. The main concern in "geographicalism" is the spatiality of scientific knowledge [3]. Therefore, the "geographical turn" is a kind of revealing of the infusion process of spatial vocabulary and languages into historical and philosophical accounts of scientific knowledge [4-8].

Geographicalism in science studies and all endeavors in this field reveal not only the power of spatialities in scientific knowledge but also the consciousness of human beings. So, to understand the nature of scientific knowledge, we must necessarily grasp the specific and inherent spatialities of the being in the world. It is critically important to pay attention to those places and spaces that have generated knowledge and then circulated and consumed it in different scales from the body to the global. At every geographical scale, "historicality", "sociality" and "spatiality" are tightly interwoven [4]. According to Soja [5], historicality, spatiality and sociality are philosophical ingredients of 'the trialectics of being'. Based on such an understanding, the geography of science and striving for putting science in its place, has developed since the early 1980s mainly with Livingstone [6,7]; Naylor [8,9]; Shapin [10]; Finnegan [11]; Powell [12]; Withers [13,14] and Meusburger [15]. The research of these geographers is basically rooted in or inspired by views and theories of Michel Foucault, Henry Lefebvre, Edward Said, Pierre Bourdieu, Clifford Geertz, Anthony Giddens, Donna Haraway, and Bruno Latour. The pivot focus of these geographers is to prove that geography (place and space) matters in the production of scientific knowledge. As Livingstone [16] (p. 3) emphasized, "space is rapidly becoming a central organizing principle for making sense of scientific knowledge."

\section{Putting spatial causalities first}

From the point of view of geography of science, scientific knowledge is not just the product of specific, individual and bounded sites, places, spaces, and regions but it is also produced through conjunctures of multitude of hybrid, relational and mobile spatialities networks. We need to reimagine production or innovation in scientific knowledge in terms of the encounter of multiplicitous relationships, rather than assuming that knowledge enters from the outside to sites or region and diffusion from the inside to the other sites and regions. Indeed, we must see knowledge and scientific activity in terms of hybrid and relational spatialities networks in a world of contingency and constant becoming. As Driver [17] (p. 388) says, "A focus on the geography of science thus implies more than an acknowledgement of the locational context of science".

As Haraway [18] argues, scientific inquiry is not the view from nowhere, but the view from somewhere. Different spatialities present distinct opportunities for producing knowledge and scientific innovations. They set off different socio-spatial processes (such as innovative milieus, networks, and clusters), induce different questions and answers, and foster different experiments and engagements. The processes to attaining new knowledge are highly spatial dependent [19]. Creativity (e.g. in science) hardly develops in the placeless realm [20] and the ubiquitous familiarity of non-places [21]. Combinatorial creativity in science requires a rich store of knowledge and the ability to form links between many different types of knowledge; that is the acceptance and rejection of scientific results depend, to a large degree, on where they were produced. In Amin and Cohendet [22] (p. 86) view the powers of context -spatial and temporal- should be placed at the cen- 
ter of any theorization of knowledge formation. Furthermore, Bathelt and Henn [23] emphasized the need for combining local/regional with national/international perspectives on knowledge flows.

Moreover, producers of scientific knowledge are not actors in the placeless world (and describing placeless as the character of scientific rationality), but they are real persons with particular kinds of bodies, histories, and interests that make a difference to the kind of knowledge produced [24]. Today, the role of face-to- face contact on fostering human capital and making innovative ideas or knowledge creation via socio-spatial interactions in terms of learning economies, learning regions, learning cities and learning community have been seen as the most important sources and the driving forces of economic development $[25,26]$.

As Soja [27] argued, the basic idea is to putting spatial (cities) causality first. He illustrates this idea more with regard to The Economy of Cities, written by Jane Jacobs in 1969. Jacobs [28] defined the city as a settlement that consistently generates its economic growth from its own localized resources. This "spark of city economic life", as she called it, clearly revolves around the stimulus and social savings that arise from dwelling together in cities rather than in rural areas. Density and cultural heterogeneity are its primary triggers. Cities concentrate need, creating many challenges to social reproduction but at the same time providing greater incentives to address problems in new ways. Cities attract newcomers of all sorts, strangers, visitors, and migrants, who often carry with them innovative ideas. With her characteristic terseness she concludes, "Without cities, we would all be poor". In other words, we would still be hunters and gatherers [29] (p. 276). This also means that the innovative knowledge or ideas development took place not only in the spatial contexts but because of the spatial causalities; that is cities. "The city ... has long since been recognized as the birthplace of innovation and creativity" [30] (p. 183), because "cities speed innovation by connecting their smart inhabitants to each other" [31] (p. 7).

\section{Conclusion}

It concluded that the development of innovative knowledge and ideas took place not only in the spatial contexts but also they occur due to the spatial causalities associated with the myriad interlinkages and interdependencies among places and operate across many spatial scales from the body to the global. "The relational approach suggests that it is crucial to study and manage the social interactions and their contingencies that are fundamental to knowledge and innovation" [32] (p. 676). Hence, we must seek knowledge in spatial encounters and betweenness of places, not merely within places. Conjunctures of the multitude of hybrid, relational and mobile spatialities networks are the laboratories of the studies of geographers of science and historians of geography in the twenty-first century.

\section{Funding}

The author received no financial support for the research, authorship, and/or publication of this article.

\section{Acknowledgments}

I am very grateful to Distinguished Professor Simin Tavallai (Department of Geographical Sciences, Kharazmi University, Iran) for her inspiring comments on drafts of this paper and their smart feedbacks.

\section{Conflicts of Interest}

The author declared no potential conflicts of interest with respect to the research, authorship, and/or publication of this article. 


\section{References}

[1] Withers, C. W., (2004) Memory and the history of geographical knowledge: The commemoration of Mungo Park, African explorer. Journal of Historical Geography, 30 (2): 316-339. DOI: 10.1016/50305-7488(03)00048-3

[2] Latour, B., (1993) We Have Never Been Modern. Cambridge, Harvard University Press.

[3] Shoorcheh, M., (2018) On the spatiality of geographic knowledge, Asian Geographer, 36 (1): 68-80. https://doi.org/10.1080/10225706.2018.1463854

[4] Soja, E. W., (1989) Postmodern Geographies: The Reassertion of Space in Critical Social Theory, London: Verso.

[5] Soja, E. W., (1996) Thirdspace, Oxford: Basil Blackwell.

[6] Livingstone, D. N., (1995) The spaces of knowledge: Contributions towards a historical geography of science. Environment and Planning D: Society and Space, 13 (1): 5-34. https://doi.org/10.1068/d130005

[7] Livingstone, D. N., (2003) Putting science in its place: Geographies of scientific knowledge. Chicago: University of Chicago Press.

[8] Naylor, S., (2005a) Introduction: Historical geographies of science: Places, contexts, cartographies. British Journal for the History of Science, 38 (1): 1-12. https://doi.org/10.1017/S0007087404006430

[9] Naylor, S., (2005b) Historical geography: Knowledge, in place and on the move. Progress in Human Geography, 29 (5): 626-634. https://doi.org/10.1191/0309132505ph573pr

[10] Shapin, S., (1998) Placing the view from nowhere: Historical and sociological problems in the location of science. Transactions of the Institute of British Geographers, New Series, 23 (1): 5-12. https://doi.org/10.1111/j.0020-2754.1998.00005.x

[11] Finnegan, D. (2008). The spatial turn: Geographical approaches in the history of science. Journal of the History of Biology, 41 (2): 369-388. https://doi.org/10.1007//10739-007-9136-6

[12] Powell, R., (2007) Geographies of science: Histories, localities, practices, futures. Progress in Human Geography, 31 (3): $309-329$. https://doi.org/10.1177/0309132507077081

[13] Withers, C. W., (2002) “The geography of scientific knowledge” in N. A. Rupke (ed.) Göttingen and the development of the natural sciences (pp 9-18). Göttingen: Wallstein.

[14] Withers, C. W., (2004) Memory and the history of geographical knowledge: The commemoration of Mungo Park, African explorer. Journal of Historical Geography, 30 (2): 316-339. https://doi.org/10.1016/S0305-7488(03)00048-3

[15] Meusburger, P., (2008) “The nexus of knowledge and space” in P. Meusburger, M. Welker, and E. Wunder (eds.) Knowledge and space: Vol. 1. Clashes of knowledge: Orthodoxies and heterodoxies in science and religion (pp 35-90). Dordrecht: Springer.

[16] Livingstone, D. N., (2010) “Landscapes of Knowledge” in P. Meusburger, D. N. Livingstone and H., Jöns, (Series ed.) Knowledge and Space: Vol. 3. Geographies of Science (pp 3-22). Dordrecht: Springer.

[17] Driver, F., (1994) Making space: territorial themes in the history of science. cultural geographies 1 (4): $386-390$. https://doi.org/10.1177/147447409400100405

[18] Haraway, D. J., (1991) Simians, Cyborgs and Women: The Reinvention of Nature. London: Free Association Books.

[19] Storper, M., and Venables, A. J., (2004) Buzz: Face-to-face contacts and the urban economy, Journal of Economic Geography 4 (4): 351-370. https://doi.org/10.1093/jnlecg/lbh027

[20] Relph, E., (1976) Place and Placelessness. London: Pion.

[21] Augé, M., (1992/1995) Non-Places: Introduction to an Anthropology of Supermodernity. London: Verso.

[22] Amin, A., and Cohendet, P., (2004) Architectures of knowledge: Firms, capabilities, and communities. Oxford, England: Oxford University Press.

[23] Bathelt, H., and Henn, S., (2014) The Geographies of Knowledge Transfers over Distance: Toward a Typology. Environment and Planning A, 46 (6): 1403-1424. https://doi.org/10.1068/a46115

[24] Barnes, T. J., (2004). Placing ideas: Genius loci, heterotopia and geography's quantitative revolution. Progress in Human Geography, 28 (5): 565-595. https://doi.org/10.1191/0309132504ph506oa

[25] Florida, R., (1995) Toward the learning region. Futures 27 (5): 527-536. https://doi.org/10.1016/0016-3287(95)00021-N

[26] Longworth, N., (2007) Learning Cities, Learning Regions, Learning Communities: Lifelong learning and local government, New York: Routledge.

[27] Soja, E. W., (2003) Writing the city spatially, City: analysis of urban trends, culture, theory, policy, action, 7 (3): $269-280$. https://doi.org/10.1080/1360481032000157478

[28] Jacobs, J., (1969) The Economy of Cities. New York: Random House.

[29] Soja, E. W., (2003) Writing the city spatially, City: analysis of urban trends, culture, theory, policy, action, 7 (3): $269-280$. https://doi.org/10.1080/1360481032000157478

[30] Camagni, R. (2011) Creativity, Culture and Urban Milieux, in L. Girard, T. Baycan and P. Nijkamp (eds) Sustainable City and Creativity, (pp 183-198), Farnham, UK: Ashgate.

[31] Glaeser, E., (2011) The Triumph of the City, New York, Penguin.

[32] Faulconbridge, J. R., (2017) Relational geographies of knowledge and innovation. In H. Bathelt, P. Cohendet, S. Henn, and L. Simon, (eds) The Elgar Companion to Innovation and Knowledge Creation. (pp 671-684) Cheltenham, Edward Elgar. 